\title{
The Judicial District of Northern Iowa
}

\author{
By LeE MCNEELY
}

Mr. McNeely, Clerk of the United States District Court for the Northern District of Iowa for 45 years, died in March at the age of 83 (See Necrology of Noted Iowans). Closely associated with many prominent Iowans in the course of his long public service, he was honored by a special session of said court at Dubuque in December, 1952, at which time he reviewed the many important changes in federal judicial proceedings since 1912 of which he had personal knowledge. His address is herewith printed in full except for introductory and concluding remarks of a general nature.

It occurred to me that it would be perhaps appropriate if I were to review some of the federal court procedural and administrative changes that have taken place during my forty years of service. There have been thirteen United States Attorneys in this District from the time it was established in 1882 down to the present time. It has been my privilege to have served with nine of them. Only four were before my term. There have been ten United States Marshals, and it has been my privilege to have served with seven of them, there being three before I came into the service. Since becoming Clerk in 1912, there have been five new federal court buildings built in this District. Fort Dodge is the only Court point where we do not have a modern building. A new one is badly needed there because of the inadequacy of the facilities. So we have five beautiful, modern Government buildings, located at Sioux City, Mason City, Waterloo, Cedar Rapids, and Dubuque. The Mason City building was occupied in 1932 and the rest of them in 1933, or very shortly thereafter. Before we had the new building at Mason City, there was no other federal building there excepting the post office. So we held Court in the court room of the County Court House. The State Court judges were cooperative and courteous. They would arrange their court terms at Mason City so that we might have the use of their court room. I had the privileges of the Clerk's office, the use of his vault for my blank forms and so on. We felt grateful to the State 
Court judges of that District and to $\mathrm{Mr}$. Stanley $\mathrm{H}$. MacPeak, Clerk of Cerro Gordo County Court.

Among the procedural and administrative changes have been:

Perhaps the most noteworthy change was the establishment of the Administrative Office of the United States Courts in 1939, representing as it does an important advancement in perfecting the administration of the Courts and the procedure as respects the personnel. When the proposition first came before the Federal Court Clerks Association it was the consensus that success or failure would depend upon how and by whom it was administered. Never since Mr. Henry P. Chandler, Director, and Mr. Elmore Whitehurst, Assistant Director, entered upon their duties and set up the organization has there been any doubt in the minds of the federal court clerks and their staffs as to the distinct success of the Administrative Office and the great good that has resulted and will continue under the present policies. Mr. Chandler and Mr. Whitehurst have a marvelous staff of Division chiefs and other helpers. In my opinion the code of procedure followed by the Administrative Office of the United States Courts is more cordial, kindly, and helpful than that of any other federal agency. Much has been accomplished in standardizing the work of the Clerks' offices, the methods have been simplified, labor-saving devices have been made available, and the interests of the Courts and of the personnel have been protected and advanced in hearings before the budget committees of the Senate and House and in other channels. The Clerks' offices throughout the country are unstinting in their praise of the achievements of the Administrative Office.

Again there was another very important move for progress with the adoption of the new Rules of Civil and Criminal Procedure. The new Criminal Rules of Procedure were adopted, effective March 21, 1946, and the Civil Rules of Procedure were adopted, effective September 1, 1948. These new Rules have resulted in uni- 
form practice in Federal Courts over the whole country and in hastening the trials and other disposition of cases. They have also effected a tremendous saving in expense to the Government and in the dispatch of business in federal courts.

We have a probation system which did not exist when I became Clerk. It has proved to be a great adjunct in the administration of justice. That office is being presently ably administered by Mr. Edward L. Anderson, who is the Chief Probation Officer for this District. We had several other fine probation officers before him.

About eight years ago there was established the official court reporter system for the Federal Courts. That position has been occupied for the past six and a half years by our superb reporter, Carl V. Riley, of Dubuque, Iowa.

There have been many changes in Naturalization proceedings. And there is a new law going into effect on December 24th which will change several of the methods of administering naturalization proceedings. At this time I would like to pay tribute to Mr. Rain of the Department of Immigration and Naturalization Service, Mr. White and others of that Service who come into the Northern District of Iowa. They have been marvelous to us. Mr. Rain spoke of my service to the public, but the services of these Examiners go far beyond mine for their courtesies to these people, many of whom are foreigners wholly unfamiliar with our way of life.

When I became Clerk there was one deputy clerk in the Dubuque office. We have four now, which includes the Cedar Rapids deputy who is stationed most of the time at Dubuque. We had one deputy at Cedar Rapids, one at Sioux City-two now-and one at Fort Dodge.

When I came in every record was made in longhand in all of the offices. Letters were copied by the old-fashioned press copy system. The letters were held until late in the day, unless there was some emergency for one to go out late in the morning, until all could be copied in the press copy book. At Sioux City, gas 
lights were still in vogue in the federal building. All of those things have been changed, and we have gone along with the advancement that science has brought. Carbon paper is now used for making copies of letters. We make our records by typewriting, and they are permanently bound into binders.

In recent years we have extended our jury system to permit women to serve as jurors. With the advent of women suffrage, women became eligible for jury service. However, for years we did not change but continued to draw men only. At Sioux City an indictment was returned, and counsel for the defendant filed a motion to quash the indictment on the ground that no women had been certified for jury service, as members of the Grand Jury panel. Judge John W. Delehant, a distinguished jurist from Nebraska, who was acting by assignment in the Northern District of Iowa, had to pass upon the question presented to him. While he said that he would rather not pass upon the question, being a visiting judge, he did take hold of it and sustained the motion to dismiss. Another Grand Jury was immediately called and the man was indicted and later tried. I believe the trial of that case was Judge Graven's first criminal case as the presiding Judge of this District. I might tell you an incident of that case. The defendant was a factory worker at the Amana Society. They were making refrigerators for the Government for the use of the Navy. This man was disgruntled because he was not permitted to take a bottle of beer into the factory. He was so put out that one night he set fire to the factory, and extensive damage was done.

Another change in jury service is that we now have professional people on our juries. An extensive survey was made some years ago, and it was found that people who were exempt from jury service were the very people who should be on juries-professional people, doctors, dentists, lawyers, teachers, nurses, superintendents of schools, and so forth. We now have people from all 
the professions called for jury service. That, of course, is a considerable change.

The matter of taking an appeal to the Court of Appeals formerly was a very tedious procedure. The appellant was required to ask the Court to grant his petition for an appeal. It was called a writ of error. It was in fact issued by the District Court itself although it was supposed to come from the Court of Appeals and the Clerk made the return to that Court with the record. That has been abolished. An appeal is now taken by filing Notice of Appeal.

When I began, following the retirement of Mr. Alonzo J. Van Duzee, in the old post office building at 9th and Locust Streets, the court room was on the third floor and the clerk's office on the second floor. That was a very unhandy layout and resulted in a lot of delays in getting papers from the Clerk's office into court. In the new buildings, the offices of the Judge, the Clerk, and all other court staff members are all on the one floor.

There has been a change in the matter of the Referee in Bankruptcy. We have one Referee for the entire District-John H. Mitchell of Fort Dodge, who unavoidably could not be here, because he is engaged in the trial of a case at Boone. He did want to be here. At one time we had eleven Referees in Bankruptcy; and at the same time we had forty-three banks as depositories for bankruptcy funds. That was really a nuisance, particularly since every depository bank had to be bonded, and the bonds had to be carefully watched. Sometimes the smaller banks would not care to purchase a corporate bond on which they would have to pay a premium, and we did not like to take a bond on which the Directors of the Bank were the surety because if the bank failed the bond would not be good with only the Directors being liable-and it was difficult to get other parties, not interested in the Bank, to go surety on the bond. We have been relieved of that, and now we have only eight banks as depositories for bankruptcy funds. 
Mr. Chandler spoke about the fee system. It is true, as he said, that the Clerk and other Court officials were dependent on the collection of fees for their compensation. That has all been changed. We have been on a fixed salary basis for quite a number of years now, but the fee system was continued until 1925. The older members of the Bar will remember this, that there were many small items. For instance, there was a ten cent charge for filing a bill of complaint; for a removal case to the District Court, there was a ten cent charge; filing a praecipe was ten cents, and making an entry fifteen cents. In those days there was a statute by which we took a commission out of every cash deposit-1 per cent. For instance, when a case was filed there was a ten dollar fee for filing the same, and against that there was a charge of ten cents. All of those small items had to be taxed and estimated in the judgment. It was really quite a vexatious task. In 1925, Congress passed a fee bill, which was a very efficient step in bringing up to date administrative details of the Clerk's office. It provided for a progressive schedule. There was a five dollar filing charge when a case was filed. If there were two or three defendants, when the answers were filed, if the interests were not identical, the first answer carried a five dollar charge, the second answer was two dollars, and if a third answer were filed, it would be three dollars. In 1944, there was passed the flat filing fee. Then, as now, when a case is filed there is a fifteen dollar deposit required, which covers all of the services of the Clerk. It has been estimated, I believe, that the Government breaks even on that as compared with what it was when we had all of the miscellaneous fees. In a case such as we read about being tried in New York, or one of the other large cities, where the trial might last several months, the fifteen dollar fee would not cover the cost to the Government. On the other hand, where we have many cases that are short and the services very limited, the Government would gain that way. So there are a lot of equalizations. These fees are paid 
into the Government by the Clerk's office in his quarterly accounting.

In the earlier days it was the law that a pending case, not continued from one Term to the next, would die with the old Term. Therefore, the Court, Counsel, and the Clerk had to be on the alert so that cases would not die under those conditions. We had to continue those cases to take care of that situation. That matter has been taken out of our duties.

Another burdensome duty was the so-called final record. It was the rule of Court that in all cases involving title to real estate, while the decrees were recorded in the minutes or the journals, we had to make a complete record of all decrees that went into the case. About twenty years ago or so, we were relieved of that.

Perhaps the most colorful case in the history of the District was the celebrated Oscar M. Hartzell case which involved the estate of Sir Francis Drake. Hartzell got people to invest in his plan. It was estimated that there were from one to two million dollars taken from people by him and his agents. The case was tried at Sioux City. $\mathrm{He}$ was convicted and went to the penitentiary. There was an amusing incident in conection with the case, as there is with many cases. Mr. Harry M. Reed of Waterloo, who I am pleased is here today, was the United States Attorney who tried the case for the Government. $\mathrm{He}$ asked one of the witnesses, "How much did you invest in this scheme?" He laughed and said, "I kind of put one over on my wife. She and I put in five hundred dollars, but without letting her know I put in five hundred dollars myself."

There have been changes in the time of holding Court. From 1907 to 1948, there were what we call the spring and fall terms. We would begin at Cedar Rapids in April and end at Dubuque with the December Term. When the new Judicial Code was enacted in 1948, the District Court Judges were given authority to fix the Terms, and under the Order of Judge Graven our Terms 
begin at Waterloo in February of each year and the last Term of the year is at Mason City in November.

For many years before and extending until just before I came into office, there were two Courts in each District-a Circuit and the District Court. In December, 1911 the Circuit Court was abolished and its jurisdiction was assigned to the District Court, and it has been so ever since. The earlier Federal Circuit Court and its jurisdiction had no relation to the Circuit Court of Appeals.

From time to time there have been changes in the counties along the borders between the Northern and Southern Districts of Iowa. Every now and then some occasion would arise and Congress would pass a law changing a county here and there from one District to the other. There are fifty-two counties having a population of $1,315,000$ people in the Northern District of Iowa, and forty-seven counties in the Southern District of Iowa. In 1916, Judge Martin J. Wade of Iowa City was appointed Judge of the Southern District of Iowa. Johnson County at that time was in the Northern District of Iowa, so Congress immediately passed a law transferring that County to the Southern District, which, of course, enabled Judge Wade to meet the requirements of the law that a Federal Judge must reside within the District over which he presides. The last County change was in 1937 when Crawford County, in the Western part of the State, was transferred from the Southern District to the Northern District which, of course, gave us the fifty-two counties.

It has been my experience during my tenure to meet and associate with many outstanding judges, members of the Bar, Court officers and personnel. It has been a great privilege and inspiration to serve with these judges. As Judge Graven said, I have been with three of the four judges who have presided over the United States District Court for this District since it was established in 1882-Judge Henry T. Reed, Judge George C. Scott, and himself. Additionally, there have been 
many excellent judges who have come into the District by special assignment when the encumbent judge was indisposed or otherwise absent, such as on special assignment to the Court of Appeals, and so forth. We have had judges come in from Minnesota, South Dakota, Nebraska, Missouri, and the Southern District of Iowa. It has been a great privilege to have had them come in and to work with them.

There have been, of course, other pleasant associations. I think that the most remarkable character was M. L. Healy of Cedar Rapids. He was a Deputy United States Marshal. Everyone who knew him referred to him as Uncle Mike. For a man who might be classed as almost illiterate, a man who had but very little book learning, he was a marvelous character, wise, prudent, and careful. I venture to say that Mike Healy saved the United States Government thousands of dollars by encouraging a defendant to plead guilty when he could do so properly and legally without making any inducement or promise to him. He had a way of handling people. They would trust him. I could tell you a lot of things about Mike. There was a constant law violator on the Indian Reservation at Tama. His name was Jim Peters. One day somebody was talking to him, and he said, "Jim, why are you always against the Government? Why are you down on the Government?" Jim Peters replied, "Me not against the Government. Mike Healy and me good friends."

Some years ago we had a Grand Jury at Cedar Rapids. At that time fifteen constituted a legal grand jury. The late Guy Linville of Cedar Rapids was the United States Attorney at that time. After presenting the evidence in a case he explained to the Grand Jury that under the law he was not permitted to be present while they were voting, but asked them to send word to him when they had finished their vote and he would proceed with the next case. Time went on and Mr. Linville felt that it had reached the point where he should make some inquiry. He knocked at the door and, called for the fore- 
man. He asked him if they had voted. The foreman responded that they had voted three or four times but each time the vote was the same, that there were fourteen votes in favor of the Government and one against conviction, and that the fourteen couldn't get the other one to switch over. Mr. Linville explained that they had overlooked the judge's instructions and that twelve votes were sufficient for indictment. So they then promptly returned an indictment.

There have been some pathetic incidents also. A few years ago we had the famous case of United States of America vs. John (Jake the Barber) Factor, et al. They were convicted of using the mails to defraud in the sale of spurious whiskey warehouse receipts. There were twelve defendants in addition to Jake the Barber who were named in the indictments. The cases were set for trial at Cedar Rapids, a hundred witnesses or more subpoenaed,and just before the trials began, they all pleaded guilty and were sentenced. The witnesses were, of course, discharged. Among them was one old gentleman who had given these racketeers seventy thousand dollars for these bogus whiskey warehouse receipts. He was given his certificate of discharge and was told to go to the Marshal's office for his money. It was there that he learned that he was to get only his transportation expense from his home at Oelwein to Cedar Rapids and his few dollars witness fee. When he learned that it was not his seventy thousand dollars that he was to get back, he, of course, broke down and cried.

Another incident involved the Tama County railroad car thieves. What they would do was, they would get into railroad merchandise cars and dump the items out along the right-of-way of the North Western Railroad and others of the gang would scoop up the articles. Finally, government officers and the railroad detectives solved the robberies. They were brought into Court at Cedar Rapids, pleaded guilty and sentenced to Leavenworth. There were nine of them. The Marshal and his deputies took them via train from Cedar Rapids to 
Marshalltown where they would change to the Chicago Great Western Road to go on to Leavenworth. While waiting for the connection at Marshalltown, a bystander spoke to one of the men whom he thought was the leader and asked, "Who are you fellows?" The prisoner was somewhat of a wag and wit responded, "This is my baseball team. We played in Cedar Rapids today and lost, and we are scheduled to play at the United States Penitentiary at Leavenworth tomorrow."

The Hartzell case was very colorful as I said. We had as a witness Mr. Charles Challen, an eminent barrister from London who came to testify about the transfer of lands in England and to show how impossible $\mathrm{Mr}$. Hartzell's position was, that he could not have possibly gotten possession of the land on which the City of London was built. Another witness was a Scotland Yard detective, a Mr. "X." He was never called as a witness but was on hand if needed in prosecution of the case.

My friends, from time to time during the years of my service, when people have complimented me for some service they received from the Clerk's office, I think that I uniformly said to them, "I don't claim to be a good, an able or efficient Clerk. But I have tried to be accommodating." I have tried to make that the policy of the Clerk's office. That beloved writer, Robert Louis Stevenson, has given to posterity a little sermon, a beautiful pattern for anybody:

To be honest, to be kind, to earn a little and spend a little less; to make upon the whole a family happier for his presence; to renounce when that shall be necessary, and not be embittered; to keep a few friends, but these without capitulation; and above all, upon the same grim condition, to keep friends with himself; here is a task for all that a man has of fortitude and delicacy. 
Copyright of Annals of Iowa is the property of State of Iowa, by \& through the State Historical Society of Iowa and its content may not be copied or emailed to multiple sites or posted to a listserv without the copyright holder's express written permission. However, users may print, download, or email articles for individual use. 